\title{
Investigating the Export Procedure Awareness of the Residents of Laligurans Municipality
}

\author{
Arjun Rai \\ Lecturer \\ Faculty of Management, Mahendra Multiple Campus, Dharan, Tribhuvan University, Nepal \\ arjun.rai@mahmc.tu.edu.np, \\ ORCID: https://orcid.org/0000-0001-9578-6971 \\ DOI: https://doi.org/10.3126/dristikon.v11i1.39125
}

\begin{abstract}
This survey examined the association between the gender of the respondents and their desire to join or form a local cooperative association, perception towards the quality of locally grown agricultural products, and practice of selling locally produced agricultural products of the residents of Musunkhel, ward number 3 of Laligurans Municipality of Tehrathum district, Province No.1, Nepal. The population in the study comprised all the households of ward number 3 of Laligurans Municipality. This survey used a standardized questionnaire to collect primary data from 92 households from the targeted area. However, this study included 79 households only. The remaining households were filtered during the data curation and cleaning process. The collected data were processed in the Statistical Package for the Social Science (SPSS), version 25. Data were analyzed using descriptive and inferential statistical tools. The study's findings indicated an insignificant association between gender and desire to join or form a local cooperative association, perception towards the quality of locally grown agricultural products, and practice of selling locally produced agricultural products. The study also found that the level of qualification does not influence awareness of the export process. However, relatively respondents with lower academic qualifications were aware of the export procedure.

Keywords: export procedure awareness, perceived quality, desire to join cooperatives, access to the local market
\end{abstract}

\section{Introduction}

\section{Background of the Study}

It is an embedded nature of human beings to seek freedom in life. Mere political freedom does not contain human desire. While enjoying other forms of freedom, human beings have other intricated desires, and economic freedom is one of many other desires. People desire to live an economically independent life. People engage in different economic activities for such economic independence, including trade, employment, or self-employment. The government of Nepal has been attempting to alleviate poverty through different policy interventions. To 
achieve poverty alleviation, the government encourages unorganized people from different sectors of the economy to form cooperatives. Thereby the people with similar economic problems work together to solve commonly faced problems.

Awareness is a key to identify and exploit opportunities. People may miss opportunities owing to a lack of knowledge. This study aimed to find out the awareness of the respondents for exporting their locally produced agricultural products. Understanding the level of awareness may help in achieving the economic growth of the area. With the new growth theory, knowledge is recognized as an essential driver of economic growth (Mueller, 2007).

\section{Research Questions}

With regard to the study material, following research issues have been accepted for the presentation, analysis and discussion:

a. Is there a significant association between gender of the respondents and their tendencies to sell their locally produced agricultural product in the local market?

b. Is there a significant association between gender and desire to join local cooperative associations for selling locally produced agricultural products?

c. Is there a significant association between gender and perception towards locally produced agricultural products' quality for export?

\section{Research Objectives}

a. To examine the association between gender and decision to sell the locally produced agricultural product in the local market.

b. To test the association between gender and desire to join local cooperative associations for selling locally produced agricultural products.

c. To investigate the association between gender and perception towards locally produced agricultural products' quality for export.

\section{Hypotheses}

The study proposes the following hypotheses:

$\mathrm{H}_{1}$ : There is no significant association between the gender of the respondent and their practice of selling their local surplus product to the local market.

$\mathrm{H}_{2}$ : There is no significant association between the gender of the respondents and their willingness to form cooperatives to sell their local surplus products.

$\mathrm{H}_{3}$ : There is no significant association between the gender of the respondents and their belief in their local products' quality for export.

\section{Significance of the Study}


The study's objective was to identify the association between the gender of the respondents and their awareness of the export procedure for locally grown agricultural products. This knowledge is helpful for local authorities if the people are unaware of the process of exporting their local agricultural products; necessary training or workshop can be conducted by the local authorities so that the local farmers can export their products to the international market. Similarly, this study examined the residents' perception of their local products' quality to compete internationally. The findings would help the local government conduct quality improvement programs if the residents perceived their product lacked the quality for export. Furthermore, the study attempted to explore the number of residents willing to join or the cooperative associations for selling their locally produced agricultural product. The local authorities, especially the municipality, can facilitate the local farmers in forming cooperative associations for selling their products. Finally, it is beneficial to understand whether local farmers sell their surplus agricultural products to the local market or not. For instance, if the residents are not selling their surplus agricultural products to the local market, the local authorities may explore its reasons and encourage the farmers to sell their local agricultural products for their economic empowerment.

\section{Limitations of the Study}

In this study, primary data was collected from Musunkhel village, ward number 3 of Laligurash municipality of Tehrathum district. It would have been better if other ward units of Laligurash Municipality were also included in this study. The study used 79 responses in this study. Thus, the sample size may create issues of generalization. The statistical tools employed in this study are descriptive. For inferential analysis, the Chi-square test was used. Other statistical tools could have been employed.

\section{Review of Literature}

Musunkhel is a village or a particular area of Ward No. 3 of Laligurans Municipality of Tehrathum district of Nepal. The present Ward No. 3 of Laligurans Municipality comprises Ward 5, 6, 7, 8, and 9 of the former Basantapur Village Development Committee. The population of Ward No. 3 is 1852 and is mainly inhabited by Brahmins, Cheetris, and Limbu people. The area covered by this ward is 6.83 square kilometers, wherein a total of 333 households reside. This ward shares boundary with ward number 2 to the North, 5 and 6 to the South and East respectively, and wards 2 and 4 to the West. The literacy rate of ward number 3 is 75.41 percent. The primary occupation of the residents of this ward is farming. (Website of Laligurans Municipality)

The role of cooperative associations in improving the economic health of people (especially economically disadvantaged) has empirically been tested by different scholars. Before presenting the arguments to highlight the role of cooperative associations, this paper 
presents the concept of cooperative associations. Dogarawa (2010) quotes the International Cooperative Alliance (I.C.A.) definition, which defines cooperative associations as autonomous associations of people voluntarily united to meet their everyday economic, social, and cultural needs and aspirations through a jointly-owned and democratically-controlled enterprise. International Cooperative Alliance (I.C.A. 2021 para.1), on its website, explains that cooperatives are people-centered enterprises owned, controlled, and run by and for their members to realize their everyday economic, social, and cultural needs and aspirations. GARANDI and HASSAN (2020) researched how participation in cooperative associations economically benefits the participants in Nigeria and found a positive impact of participation on the economic condition of the participants. This study investigated the number of respondents willing to join cooperative associations to sell their locally grown agricultural harvests.

Awareness is a critical driver in exploring economic opportunities and their exploitation. Mueller (2007) opined that awareness or knowledge With the new growth theory, knowledge is recognized as an essential driver of economic growth. With this assertion, it can be postulated that if the residents of Musunkhel are aware of exporting their locally grown agricultural products, they can export their local products to the international market and improve their economic wellbeing.

\section{Materials and Methods}

This study is quantitative research. The data was collected from Musunkhel-3, a ward unit of Laligurans Municipality, of Tehrathum, Nepal. A field visit was made to the targeted population. The population of the study includes all the residents of Laligurans Municipality, ward number 3. The data was collected through a structured questionnaire. The questions contained in the questionnaire were read to the respondents. Hence, the data was collected. Primary data was collected from seventy-nine households located in Musunkhel area of Laligurans Municipality, Tehrathum District of Nepal. The collected data were coded, entered, and analyzed in the Statistical Package for the Social Science (26). This study used a descriptive method of research design to describe the characteristics of the sample units, and inferential statistics were used to infer the characteristics of the sample to the population.

\section{Results and Discussion}

\section{Data Analysis}

Table 1

Gender, Religion, and Educational Profile of the Respondents

\begin{tabular}{llcc}
\hline Variables & Groups & Frequency & Valid Percent \\
\hline \multirow{2}{*}{ Gender } & Male & 43 & 54.4 \\
& Female & 36 & 45.6
\end{tabular}




\begin{tabular}{llcc}
\multirow{5}{*}{ Religion } & Buddhist & 2 & 2.5 \\
& Hindu & 74 & 93.7 \\
& Kirat & 2 & 2.5 \\
& Maouhang & 1 & 1.3 \\
& Illiterate & 23 & 29.1 \\
& Below S.L.C. & 31 & 39.2 \\
\multirow{5}{*}{ Education } & SLC & 14 & 17.7 \\
& Higher Secondary & 6 & 7.6 \\
& Bachelors & 4 & 5.1 \\
& Masters & 1 & 1.3 \\
\hline
\end{tabular}

Table 1 presents the demographic summary of the respondents of Musunkhel village, a ward unit of Laligurans Municipality of Tehrathum District. Out of 79 respondents of the study, 54.4 percent of respondents were males, and 45.6 percent were female respondents. Further, the religious profile of the respondents shows that the majority of the respondents of the study were Hindus. Out of 79 households, 93.7 percent of respondents practiced the Hindu religion. Kirat and Buddhist religion practicing household recorded to be 2.5 percent for each religion. Likewise, the educational profile of the respondents revealed that out of 79 respondents, 39.2 percent of respondents' educational qualification was below the then S.L.C (School Leaving Certificate, which is equivalent to the Secondary Education Examination level). The data shows that as the educational level becomes higher, the number of people attaining higher education decreases. Out of 79 respondents, only one respondent had completed the Master's level of education.

Table 2

Occupational Profile of the Respondents

\begin{tabular}{llcc}
\hline Variables & Groups & Frequency & Valid Percent \\
\hline \multirow{7}{*}{ Occupations } & Farming & 55 & 70.5 \\
& Business & 1 & 1.3 \\
& Overseas & 1 & 1.3 \\
& Housewife & 11 & 14.1 \\
& Student & 3 & 3.8 \\
& Tailoring & 2 & 2.6 \\
& Driving & 1 & 1.3 \\
& Teaching & 4 & 5.1 \\
Total & Undisclosed & 1 & \\
\hline & & 79 & \\
\hline
\end{tabular}


Table 2 presents the occupational profile of the respondents of the study. Out of 79 respondents from Musunkhel village of Laligurash Municipality, most respondents reported farming as their occupation (70 percent). Approximately 14 percent of the respondents were housewives, followed by 5.1 percent respondents with teaching occupations. The number of people involved in business, overseas employment, and driving occupation was the least, accounting for 1.3 percent. Out of 79 respondents, one respondent did not disclose his/her occupation.

Table 3

Comparison of E.A., P.Q., D.J.C., L.M.S. by Educational

\begin{tabular}{|c|c|c|c|c|c|c|c|c|}
\hline \multirow[b]{2}{*}{ Variables } & \multirow[b]{2}{*}{ Responses } & \multicolumn{6}{|c|}{ Education } & \multirow[b]{2}{*}{ Total } \\
\hline & & Illiterate & $\begin{array}{l}\text { Below } \\
\text { SLC }\end{array}$ & SLC & $\begin{array}{c}\text { Higher } \\
\text { Secondary }\end{array}$ & Bachelors & Masters & \\
\hline \multirow{4}{*}{ SLM } & \multirow{2}{*}{ Yes } & 20 & 21 & 12 & 4 & 3 & 0 & 60 \\
\hline & & $87.0 \%$ & $67.7 \%$ & $85.7 \%$ & $66.7 \%$ & $75.0 \%$ & $0.0 \%$ & $75.9 \%$ \\
\hline & \multirow{2}{*}{ No } & 3 & 10 & 2 & 2 & 1 & 1 & 19 \\
\hline & & $13.0 \%$ & $32.3 \%$ & $14.3 \%$ & $33.3 \%$ & $25.0 \%$ & $100.0 \%$ & $24.1 \%$ \\
\hline \multirow{4}{*}{ DJC } & \multirow{2}{*}{ Yes } & 12 & 22 & 6 & 3 & 2 & 1 & 46 \\
\hline & & $52.2 \%$ & $71.0 \%$ & $42.9 \%$ & $50.0 \%$ & $50.0 \%$ & $100.0 \%$ & $58.2 \%$ \\
\hline & \multirow{2}{*}{ No } & 11 & 9 & 8 & 3 & 2 & 0 & 33 \\
\hline & & $47.8 \%$ & $29.0 \%$ & $57.1 \%$ & $50.0 \%$ & $50.0 \%$ & $0.0 \%$ & $41.8 \%$ \\
\hline \multirow{4}{*}{ PQ } & \multirow{2}{*}{ Yes } & 12 & 15 & 7 & 4 & 2 & 0 & 40 \\
\hline & & $52.2 \%$ & $50.0 \%$ & $50.0 \%$ & $66.7 \%$ & $50.0 \%$ & $0.0 \%$ & $51.3 \%$ \\
\hline & \multirow{2}{*}{ No } & 11 & 15 & 7 & 2 & 2 & 1 & 38 \\
\hline & & $47.8 \%$ & $50.0 \%$ & $50.0 \%$ & $33.3 \%$ & $50.0 \%$ & $100.0 \%$ & $48.7 \%$ \\
\hline \multirow{4}{*}{ EA } & \multirow{2}{*}{ Yes } & 1 & 2 & 3 & 0 & 1 & 0 & 7 \\
\hline & & $4.3 \%$ & $6.5 \%$ & $21.4 \%$ & $0.0 \%$ & $25.0 \%$ & $0.0 \%$ & $8.9 \%$ \\
\hline & \multirow{2}{*}{ No } & 22 & 29 & 11 & 6 & 3 & 1 & 72 \\
\hline & & $95.7 \%$ & $93.5 \%$ & $78.6 \%$ & $100.0 \%$ & $75.0 \%$ & $100.0 \%$ & $91.1 \%$ \\
\hline
\end{tabular}

Notes. Where EA= Export Awareness, $\mathrm{PQ}=$ Perceived Quality for Export, DJC $=$ Desire to Join Cooperatives, LMS= Local Market Sales.

Table 3 presents a comparison of respondents' practices of selling their local agricultural products to the local market, desire to join cooperatives for selling their local agricultural products, respondents' perception towards their products' export quality, and the respondents' awareness of the export procedure by the educational qualifications the respondents. Among the illiterate respondents, 87 percent sold their harvest in the local market, while 13 percent did not. Additionally, only 67.7 percent of the respondents with educational qualifications below S.L.C. sold their harvest in the local market, and the rest of these respondents did not. 
Furthermore, 85.7 percent of respondents with educational qualifications of S.L.C. sold their harvest in the local market, and the rest, 14.3 percent, did not. Similarly, 66.7 percent of the respondents with educational qualifications of Higher Secondary Level sold their harvest in the local market, the rest 33.3 percent did not sell their harvest in the local market. Thus, the percentage of the respondents selling their harvest in the local market is 75 percent for the Bachelor's qualified respondents, while the only respondent with a Master's Degree did not sell his/her harvest in the local market. From this data, it can be seen that the highest percentage of illiterate respondents sold their harvest in the local market, while the percentage of respondents selling their harvest in the local market with a Master's degree is 0 percent. From this, it can be inferred that the illiterate respondents' only source of income might be the sales of their local harvest, but for the educated respondents, their source of income might be different. However, further research is necessary to conclude this inference.

Additionally, looking at the desire of the respondents to join cooperatives for selling their local agricultural products, it can be seen that 52.2 percent of the illiterate respondents expressed their desire to join cooperatives while 47.8 percent did not want to do so.

Furthermore, 71 percent of the respondent with educational qualifications wanted to join the cooperative, and the rest did not. Similarly, 42.9 percent of the respondents with educational qualifications of S.L.C. wanted to join a cooperative, but 57.1 percent did not want to join a cooperative to sell their agricultural products. Additionally, the percentage of respondents desiring to join cooperative is 50 percent each for the respondents with Higher Secondary and bachelor-level qualifications. Nevertheless, the only respondent with a master's degree is open to joining cooperatives for selling local products. It can be seen that although the highest percentage of illiterate respondents sold their harvest in the local market, only 52.2 percent expressed their desire to join cooperatives. However, the only respondent with the Master's degree was open to the idea of joining a cooperative to sell the local harvest, although he/she did not sell the harvest in the local market. This shows that educational level might play a role in awareness about the importance of cooperative societies. However, since only 50 percent of the respondents with educational qualifications of Higher Secondary and Bachelor's level each desired to join cooperatives, the link between educational level and cooperative awareness cannot be concretely established.

Similarly, comparing the respondents' perception towards their products' export quality across the educational level, we can see that 52.2 percent of the illiterate respondents feel that their products are export quality, and 47.8 percent do not feel so. Furthermore, 50 percent of the respondents with educational qualifications below S.L.C. feel that their product is of export quality. The same percentage (50 percent) of the respondents with educational qualifications of S.L.C. feel the same. Additionally, 66.7 percent of the respondents with higher Secondary Level educational qualifications feel that their product is of export quality, and 33.3 percent of 
these respondents do not feel so. Only 50 percent of the respondents with Bachelor's degrees feel that their products are of export quality, while the only respondent with a Master's degree does not feel that the local products are of export quality. This data shows that not many respondents, irrespective of their education, feel that their products have the quality to be exported. Finally, comparing the awareness of export procedure among the respondents across the educational level, we can see that only 4.3 percent of the illiterate respondents are aware of the export procedure while a whopping 95.7 percent are unaware.

Similarly, a mere 6.5 percent of the respondents with educational qualifications below S.L.C. are aware of the export procedure, and 93.5 percent of the same respondents are unaware. Additionally, 21.4 percent of the respondents with educational qualifications of S.L.C. level are aware of the export procedure, and 25 percent of the respondents with Bachelor's degree are aware of the export procedure. These are the second-highest and the highest percentage of respondents with export awareness, respectively, while 0 percent of the respondents with higher secondary education and 0 percent of the respondents with Master's degree are aware of the export procedure. Thus, the data shows that most respondents, including the highly educated, are unaware of the export procedure. The Comparative Table shows no noticeable relationship between the respondents' educational level and export awareness. For example, the data reveals that the respondents are aware of the export procedure although their educational qualification is relatively lower. It may imply that awareness of the export procedure may be more relative to practical issues (where an individual can perform specific tasks, not because of educational qualification, instead due to practice and experience) than educational. On the other hand, the knowledge of export procedures may be technical; although the respondents do not have the educational qualification, they might have experience exporting their products to the international market.

Table 4

\begin{tabular}{|c|c|c|c|c|c|c|c|c|c|}
\hline \multirow{2}{*}{ Variables } & \multirow{2}{*}{ Categories } & \multicolumn{2}{|r|}{ Gender } & \multirow{2}{*}{ Total } & \multicolumn{4}{|c|}{$\chi^{2}-$ statistic } & \multirow[t]{2}{*}{ Decision } \\
\hline & & Male & Female & & $x^{2}$ & $\mathrm{df}$ & $\mathrm{P}$ & $\mathrm{N}$ & \\
\hline \multirow{4}{*}{ LMS } & & 32 & 28 & 60 & \multirow{4}{*}{$.121 \mathrm{a}$} & \multirow{4}{*}{1} & \multirow{4}{*}{0.728} & \multirow{4}{*}{79} & \multirow{4}{*}{ Accept $\mathrm{H}_{1}$} \\
\hline & Yes & $74.4 \%$ & $77.8 \%$ & $75.9 \%$ & & & & & \\
\hline & & 11 & 8 & 19 & & & & & \\
\hline & No & $25.6 \%$ & $22.2 \%$ & $24.1 \% \mathrm{t}$ & & & & & \\
\hline \multirow{3}{*}{ DJC } & Yes & 25 & 21 & 46 & \multirow{3}{*}{$.000 \mathrm{a}$} & \multirow{3}{*}{1} & \multirow{3}{*}{0.986} & \multirow{3}{*}{79} & \multirow{3}{*}{ Accept $\mathrm{HO}_{2}$} \\
\hline & ye & $58.1 \%$ & $58.3 \%$ & $58.2 \%$ & & & & & \\
\hline & No & $\begin{array}{r}18 \\
41.9 \%\end{array}$ & $\begin{array}{r}15 \\
41.7 \%\end{array}$ & $\begin{array}{r}33 \\
41.8 \%\end{array}$ & & & & & \\
\hline PQ & Yes & $\begin{array}{r}21 \\
50.0 \%\end{array}$ & $\begin{array}{r}19 \\
52.8 \%\end{array}$ & $\begin{array}{r}40 \\
51.3 \%\end{array}$ & $.060 \mathrm{a}$ & 1 & 0.807 & 78 & Accept $\mathrm{H}_{3}$ \\
\hline
\end{tabular}




\begin{tabular}{|c|c|c|c|c|}
\hline & No & $\begin{array}{r}21 \\
50.0 \%\end{array}$ & $\begin{array}{r}17 \\
47.2 \%\end{array}$ & $\begin{array}{r}38 \\
48.7 \%\end{array}$ \\
\hline \multirow{4}{*}{ EA } & & 5 & 2 & 7 \\
\hline & Yes & $11.6 \%$ & $5.6 \%$ & $8.9 \%$ \\
\hline & $\mathrm{N}$ & 38 & 34 & 72 \\
\hline & No & $88.4 \%$ & $94.4 \%$ & $91.1 \%$ \\
\hline
\end{tabular}

Note. 0 cells ( 0.0 percent) have an expected count of less than 5 . The minimum expected count is 11.02 .a

Where EA= Export Awareness, $\mathrm{PQ}=$ Perceived Quality for Export, $\mathrm{DJC}=$ Desire to Join Cooperatives, $\mathrm{LMS}=$ Local Market Sales

Table 4 presents the Chi-Square test summary. Chi-Square test was conducted to examine the association between gender of the respondents, and their likelihood of selling the locally grown harvest to the local market, desire to sell local harvest through cooperatives, and perceived qualitativeness of locally grown products. The Chi-square test revealed an insignificant association between gender and the likelihood of selling locally grown harvest to the local market $X^{2}(1, \mathrm{~N}=79)=.121, \mathrm{p}>.05$. Similarly, a test of association between gender and desire of the respondents to sell their local harvest through cooperatives revealed $X^{2}(1, \mathrm{~N}=79)=$ $.000, p>.05$, indicating an insignificant association between the tested variables. Likewise, the Chi-square test for association between gender and perceived qualitativeness of locally grown harvest revealed an insignificant association between the tested variables $X^{2}(1, \mathrm{~N}=78)=.060$, $\mathrm{p}>.05$.

\section{Conclusion}

This study attempted to find out the association of the variable "gender" with other variables viz. "Selling local harvest to the local market," "Desire to sell local harvest through cooperatives," and "Perceived qualitativeness of locally produced products. Data were collected from 92 households from Musunkhel Village of Laliguras Municipality of Tehrathum District. However, only 79 households were included in the analysis since the other responses were incomplete, containing missing information on categorical variables. The analysis of the data indicated an insignificant association between the above-tested variables.

The demographic analysis of the respondents revealed that the majority of the respondents of the study were males - similarly, the religious profile of the respondents of the practiced Hindu religion. Further, the educational profile of the respondents exhibited that the majority of them had a below School Leaving Certificate level of qualification. Out of 79 respondents included in this study, only one respondent had completed a Master's Degree. Finally, the Occupational Profile suggested that most of the respondents' were involved in farming. 


\section{Implications}

A gender-wise comparison of export procedure awareness indicated that both the genders' awareness of export procedure is relatively lower. However, the comparison of export procedure awareness of males is insignificantly higher than females' awareness of the export procedure. Similarly, when the number of males and females selling their local harvest to the nearby market was analyzed, the result indicated that most male respondents sold their locally produced agricultural products to the local market. Likewise, both genders believed that their locally grown agricultural products have the quality for export.

\section{References}

Dogarawa, A. B. (2010). The role of cooperative societies in economic development. Available at SSRN 1622149.

Garandi, I., \& Hassan, S. (2020). Effect of Participation in Cooperative Society on SMES Activities of Members in Mubi Metropolis, Adamawa State, Nigeria.

International Cooperative Alliance (I.C.A. 2021) https://www.ica.coop/en/cooperatives/whatis-a-cooperative [date accessed: 12 June 2021]

Laligurans Municipality website Available at: https://laliguransmun.gov.np/en/content/ percentE0 percent 44 percentB 5 percentE0 percent 44 percentA 1 percentE0 percentA 4 percentBE- percentE0 percentA4 percent $\mathrm{A} 8$ percentE0 percent $\mathrm{A} 4$ percent82percentE0 percentA5 percentA9 [date accessed: 12 June 2021]

Mueller, P. (2007). Exploiting entrepreneurial opportunities: The impact of entrepreneurship on growth. Small Business Economics, 28(4), 355-362. 